\title{
A new species of Lacinius in amber (Arachnida: Opiliones)
}

\author{
P. G. Mitov ${ }^{1}$, J. A. Dunlop ${ }^{2}$, and D. Penney ${ }^{3}$ \\ ${ }^{1}$ Department of Zoology and Anthropology, Faculty of Biology, University of Sofia, 8 Dragan Tsankov Blvd., \\ 1164 Sofia, Bulgaria \\ ${ }^{2}$ Museum für Naturkunde, Leibniz Institute for Evolution and Biodiversity Science, Invalidenstrasse 43, \\ 10115 Berlin, Germany \\ ${ }^{3}$ Faculty of Life Sciences, University of Manchester, Oxford Road, Manchester M13 9PL, UK
}

Correspondence to: J. A. Dunlop (jason.dunlop@mfn-berlin.de)

Received: 11 June 2014 - Revised: 10 August 2014 - Accepted: 11 August 2014 - Published: 2 December 2014

\begin{abstract}
A new specimen of Lacinius Thorell, 1876; (Opiliones: Phalangiidae) from Eocene Baltic amber is described. We interpret it as conspecific with a slightly younger record from the German Bitterfeld amber, originally referred to as the extant species L. erinaceus Starega, 1966. Our new specimen reveals pedipalpal apophyses on both the patella and the tibia, features which we can now confirm in the Bitterfeld fossil too. This unique character combination for the genus justifies a new, extinct species: Lacinius bizleyi sp. nov. The Baltic amber inclusion dates to ca. 44-49 Ma, and is thus the oldest putative example of Lacinius in the fossil record. It is a further example of an arachnid species shared between Baltic and Bitterfeld amber.
\end{abstract}

\section{Introduction}

Harvestmen in the genus Lacinius (Opiliones: Phalangiidae) Thorell, 1876 are typically characterized by a distinctive spiny ornament across the legs and body. Lacinius is currently represented by seven Recent species (Table 1), six of which are found in central Europe down into the Balkans and the Mediterranean, as well as in northern Africa, Turkey and the Caucasus (e.g. Kraus, 1961; Šilhavý, 1956, 1965; Staręga, 1966, 1976; Marcellino, 1975; Martens, 1978; Prieto, 2003, 2008; Novak, 2005; Çorak et al., 2008, 2014; Sánchez-Cuenca and Prieto, 2014). Additionally, one species is recognized from the USA (Banks, 1893), while a further putative American Lacinius was synonymized with a species in Odiellus Roewer, 1923 by Cokendolpher and Lee (1993). Note that the online species lists assembled by Hallan (2005) did not always include all published synonyms, compared with Crawford (1992). Over-reliance on such online data for harvestman taxonomy - and the resulting risk of errors being copied and multiplied into other publications or resources was recently critiqued by Schönhofer (2013). Similarly, the Lacinius species from China listed in Hallan (2005), Lacinius bidens (Simon, 1880) (Acantholophus bidens; Simon, 1880), has long been referred to as Bidentolophus Roewer, 1912 (see Roewer, 1912, 1923; Wang, 1953; Li and Song, 1993), which is a junior subjective synonym of Lacinius Thorell, 1876 (see Crawford, 1992: p. 13). Note also that the Spanish species L. carpetanus (Rambla, 1959) was recently transferred to Odiellus by Sánchez-Cuenca and Prieto (2014). As shown in Table 1, three of the six Recent Palearctic species are fairly widely distributed across Europe (often through into Turkey). Others are more restricted and local in their ranges.

A few years ago, a remarkable fossil assignable to Lacinius was documented by Dunlop and Mitov (2009) from the Bitterfeld (or Saxon) amber of eastern Germany, a locality whose age has been disputed - reviewed by Dunlop (2010) - but which has recently been considered to be Oligocene (ca. 24-25 Ma) and thus younger than the better known Eocene (ca. 44-49 Ma) Baltic amber. In their original description, Dunlop and Mitov (2009) considered their Lacinius fossil to be anatomically indistinguishable from the Recent species Lacinus erinaceus (Starega, 1966), and tentatively assigned the amber inclusion to this taxon. This extant harvestman was first described from Abkhazia in the Caucasus Starega, 1966, and was later documented from the provinces of Bayburt and Gümüşhane in northeastern Turkey too (Kurt and Erman, 2012).

Recently, a second example of a spiny, Lacinius-like fossil in amber became available, this time from Baltic amber. This 
Table 1. Summary of the seven living and one fossil $(\dagger)$ species belonging to the harvestman genus Lacinius (Phalangiidae; Thorell, 1876) currently recognized in the literature.

\begin{tabular}{|c|c|c|}
\hline Taxon & Distribution & Reference(s) \\
\hline $\begin{array}{l}\text { Lacinius angulifer (Simon, } \\
\text { 1878) }\end{array}$ & $\begin{array}{l}\text { Northern Africa (Algeria, } \\
\text { Morocco), France (Corsica), } \\
\text { ?Spain }\end{array}$ & $\begin{array}{l}\text { Simon (1878), Roewer (1912, 1923, } \\
\text { 1957), Kraus (1959, 1961), Prieto } \\
\text { (2003), Delfosse }(2014)\end{array}$ \\
\hline$\dagger$ Lacinius bizleyi sp. nov. & $\begin{array}{l}\text { Europe: Bitterfeld and Baltic } \\
\text { amber }\end{array}$ & Dunlop and Mitov (2009), this study \\
\hline $\begin{array}{l}\text { Lacinius dentiger (Koch, } \\
1848)\end{array}$ & $\begin{array}{l}\text { Europe (excluding the north- } \\
\text { ernmost part) }\end{array}$ & $\begin{array}{l}\text { Staręga (1976), Martens (1978), } \\
\text { Rozwałka et al. (2010) }\end{array}$ \\
\hline $\begin{array}{l}\text { Lacinius ephippiatus (Koch, } \\
\text { 1835) }\end{array}$ & Europe, Turkey & $\begin{array}{l}\text { Staręga }(1976), \text { Martens (1978), Çorak } \\
\text { et al. }(2008,2014)\end{array}$ \\
\hline $\begin{array}{l}\text { Lacinius erinaceus Starega, } \\
1966\end{array}$ & Caucasus, Turkey & Staręga (1966), Kurt and Erman (2012) \\
\hline $\begin{array}{l}\text { Lacinius horridus (Panzer, } \\
\text { 1794) }\end{array}$ & $\begin{array}{l}\text { Europe (excluding the north- } \\
\text { ernmost part), Turkey, Iran }\end{array}$ & $\begin{array}{l}\text { Roewer (1959), Staręga (1976), } \\
\text { Martens (1978) }\end{array}$ \\
\hline $\begin{array}{l}\text { Lacinius insularis Roewer, } \\
1923\end{array}$ & Crete & $\begin{array}{l}\text { Roewer (1923), Martens (1966), } \\
\text { Chatzaki et al. (2009) }\end{array}$ \\
\hline $\begin{array}{l}\text { Lacinius texanus Banks, } \\
1893\end{array}$ & USA: eastern Texas, Georgia & $\begin{array}{l}\text { Banks (1893, 1901), Roewer (1912, } \\
\text { 1923), Crosby and Bishop (1924) }\end{array}$ \\
\hline
\end{tabular}

small specimen (Figs. 1-2), a little over a millimetre long, is probably immature, but immediately caught our attention for possessing distinct apophyses on the pedipalp, different from the morphology of any of the living Lacinius species described to date. Baltic and Bitterfeld amber are known to host a number of arachnid species in common - including some harvestmen (Dunlop and Mitov, 2009) - a fact which led some authors to consider the two ambers to be of the same stratigraphic age. Here, we demonstrate that the new specimen does belong to Lacinius and that the Baltic and Bitterfeld examples are probably conspecific. However, their pedipalp morphology differs from Lacinus erinaceus (and other extant species); thus, we suggest that both amber specimens should be referred to as a new taxon.

\section{Material and methods}

The new specimen from Baltic amber was acquired by one of us (D. Penney) via Jonas Damzen (Vilnius). It has now been deposited in the amber collection of the $\mathrm{Mu}$ seum für Naturkunde (MfN) Berlin under repository number MB.A. 2815 for "Museum Berlin, Arthropoda". It was drawn under a Leica MZ12.5 stereomicroscope with a camera lucida attachment and photographed immersed in water on a Leica Z16 microscope running the Leica Application Suite software package for generating stacks of images in different focal planes. These were combined into final pictures using
Helicon Focus and edited in Adobe Photoshop. All measurements in the descriptions are in millimetres.

The new fossil was compared to the previous amber Lacinius specimen, again in the MfN under repository number MB.A 1661. We also examined alcohol-preserved specimens (adults and juveniles) of recent Lacinius species and other phalangiid harvestmen in the zoological collections of the MfN, as well as material from the private collection of P. G. Mitov. These were compared with published descriptions from the literature (e.g. Roewer, 1923). We also consulted images of living species kindly provided by Christian Komposch (Graz) - see also Fig. 3 - and Nataly Snegovaya (Baku).

\section{Systematic palaeontology}

Order Opiliones Sundevall, 1833

Family Phalangiidae Latreille, 1802

Genus Lacinius Thorell, 1876

\section{Lacinius bizleyi sp. nov.}

Figs. 1-2

2009 ?Lacinius erinaceus (Starega, 1966; Dunlop and Mitov, 368-369; Figs. 27, 31-32 - misidentification)

Type material. Holotype, Museum für Naturkunde Berlin, MB.A. 1661. 


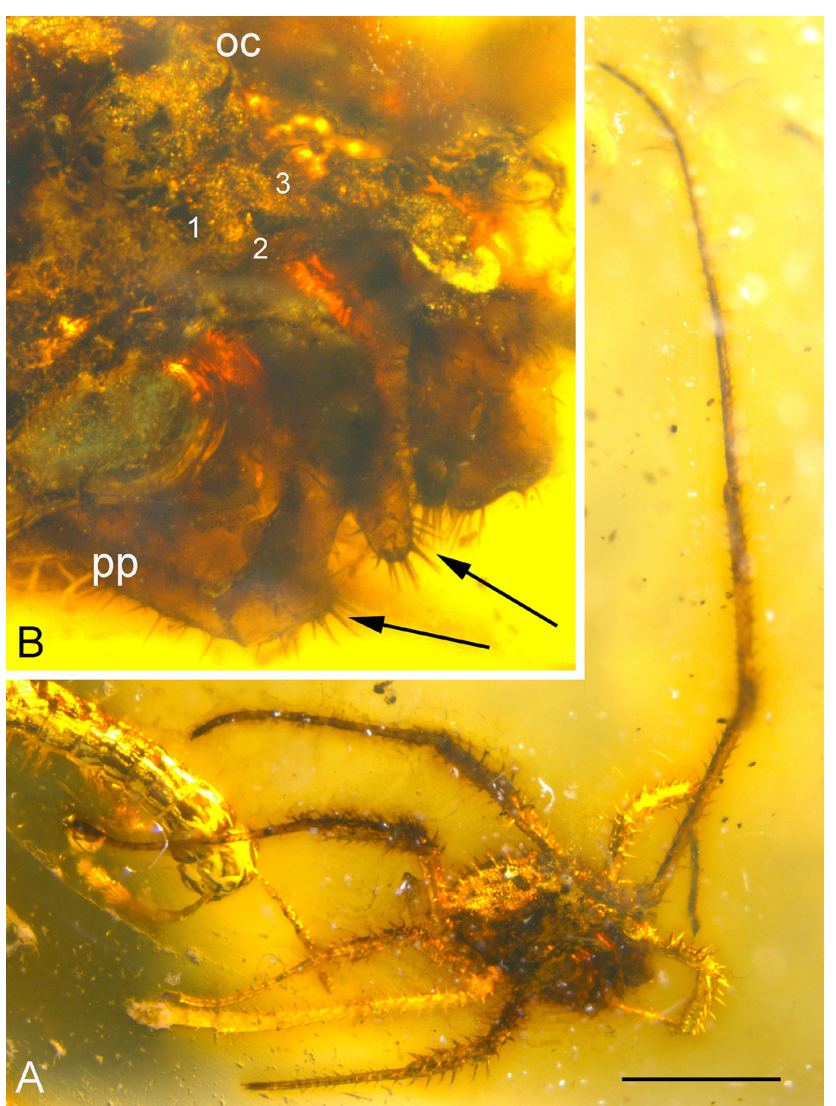

Figure 1. Lacinius bizleyi sp. nov. MB.A. 2815 from Eocene (Lutetian) Baltic amber. At ca. 44-49 Ma, this is the oldest putative record of the genus. (a) Overview. (b) Detail of the anterior prosoma showing the ocularium (oc), the three spines in front of this and the distinct apophyses on the patella and tibia (arrowed) of the pedipalp (pp). Scale bar equals $1.0 \mathrm{~mm}$.

Type locality and horizon. From Bitterfeld amber, SaxonyAnhalt, Germany. Palaeogene (?Oligocene). Described in detail by Dunlop and Mitov (2009).

Additional material. MB.A. 2815 (ex D. Penney coll., via J. Damzen). Baltic amber; precise locality not recorded, but most of the recently acquired material stems from the Kaliningrad region of the Russian Baltic coast. Palaeogene (Eocene: Lutetian).

Derivation of name. In honour of the British palaeoartist Richard Bizley (Lyme Regis) for his assistance to D. Penney with various palaeontology-related projects.

Diagnosis. Species of Lacinius with a combination of ornamented body and leg articles (except tarsi) with numerous long sharp-pointed/tipped thorns, and distinct apophyses on both the patella and tibia of the pedipalp; patellar apophysis longer than tibial apophysis.

Description of MB.A. 2815. Relatively complete specimen (right leg II mostly missing), best seen in dorso-lateral view (Figs. 1-2). Body oval, flattened, length ca. $1.2 \mathrm{~mm}$; maximum width of prosoma ca. $1.0 \mathrm{~mm}$, of opisthosoma

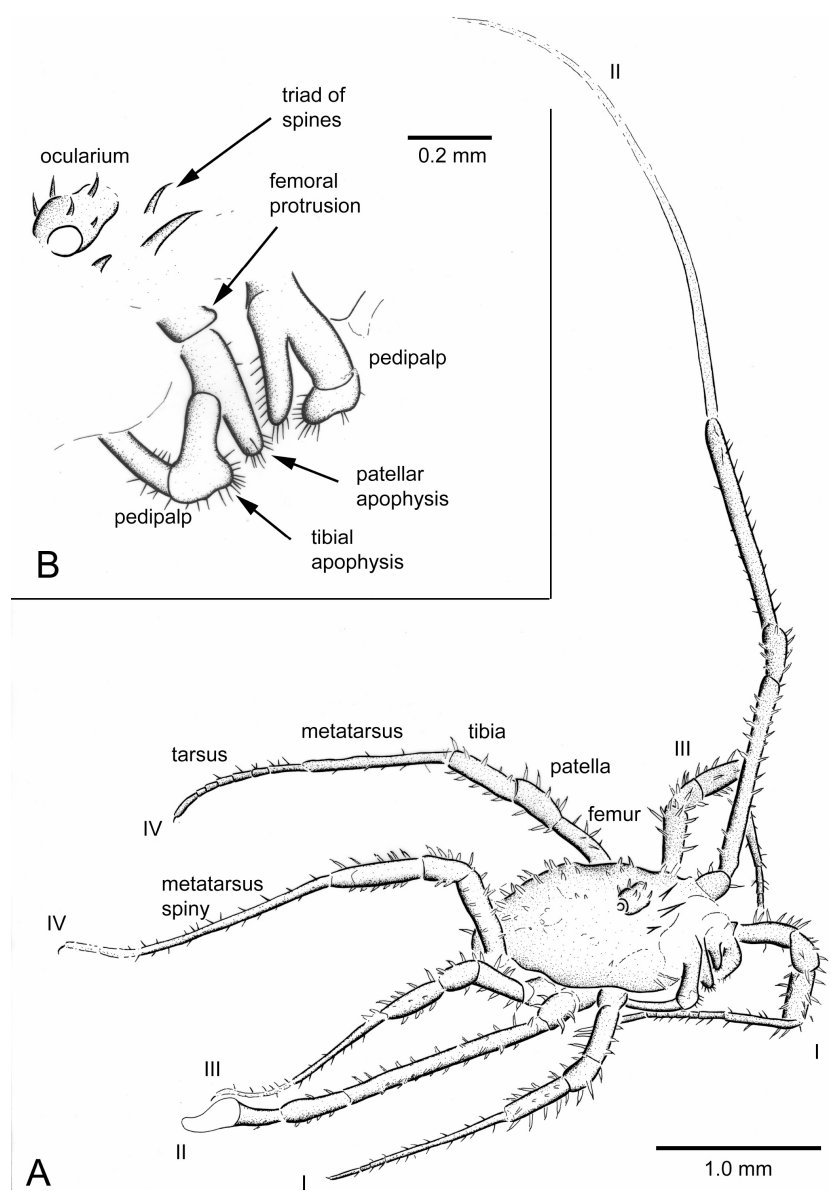

Figure 2. Camera lucida drawings of the specimen shown in Fig. 1. (a) Overview. (b) Detail of the anterior prosoma. Legs numbered from I to IV.

ca. $0.9 \mathrm{~mm}$. Ocularium raised and ornamented with at least five curving thorns (whereby thorns here have a thick base and then taper about midway along their length into a sharp spine); ocularium length and width ca. 0.14 and $0.23 \mathrm{~mm}$ respectively, distance from front of carapace ca. $0.2 \mathrm{~mm}$. Distinct pattern of triad of forward-projecting spines immediately in front of ocularium (Figs. 1a, 2b). Opisthosoma, particularly the posterior portion, ornamented with numerous backwards-pointing thorns, each consisting of a thicker base with a short, stiff seta at the tip. Chelicerae equivocal. Pedipalps with distinct apophyses projecting from both patella and tibia (Figs. 1a, 2b). Palpal femur disto-medial with one setose, apophysis-like protrusion. Patellar apophysis long, somewhat spatulate - almost reaching length of tibia - and highly setose on its mesal surface as well as apophysis tip. Tibial apophysis short and blunt, projecting mesally and again bearing numerous setae. Legs moderately long, leg II markedly longer than others (leg formula from longest to shortest: II, IV, III, I); approximate total lengths: I, $2.0 \mathrm{~mm}$; II, $6.0 \mathrm{~mm}$; III, $2.4 \mathrm{~mm}$; IV, $3.2 \mathrm{~mm}$. Trochanter, femur, patella and tibia of all legs more robust, again with 
distinct arrangement of thorns topped with stiff setae, arranged in discrete rows along length of limb article. Tibia to tarsus more slender. Basal part of the tibia with two robust thorns; distal portion of the legs otherwise with stiff setae only. Metatarsi dorsally bear short thorns and strong setae. Tarsi subdivided into ca. seven tarsomeres in each leg where visible (exact number equivocal on some legs); proximal and distal-most tarsomeres longer than those in between. All legs end, where preserved, in a single, curved claw. Genital characters could not be resolved.

Discussion. The new Baltic amber fossil is similar in habitus to the previous record from Bitterfeld, which Dunlop and Mitov (2009, Figs. 27, 31-32) tentatively assigned to Lacinius erinaceus. In the present study, we also considered a similar-looking, spiny harvestman genus: Homolophus Banks, 1893. For details of this taxon, see e.g. published descriptions of $H$. afghanus (Roewer, 1956), H. chitralensis (Roewer, 1956), H. trinkleri (Roewer, 1956) and H. turcicus (Roewer, 1959). Note that Roewer (1956, 1959) originally described these species under Euphalangium; for a generic synonymy, see Cokendolpher (1987). We also consulted Snegovaya's recent (2012) description of Homolophus nakhichevanicus Snegovaya, 2012. We believe that we can exclude the amber inclusions from Homolophus based on the presence in the fossils of a triad of spines at the front of the carapace (Figs. 1b, 2b) and the additional presence of spines on the metatarsi of the legs (Fig. 2a). In many Homolophus species, there are two principal, diverging forward-pointing spines - or "Gabelzähnchen" - at the front of the carapace, surrounded by a group of denticles sometimes forming a crown. The remaining Homolophus species only have a group of frontal denticles. Furthermore, the metatarsi of the legs of Homolophus are normally smoother than the spiny metatarsi seen in the amber specimens; only some Homolophus species have denticles/tubercles ventrally.

We thus believe that both amber fossils can be comfortably referred to as Lacinius, although the absence of genital characters in these inclusions will always preclude an unequivocal assignment. The fossils are more spiny than the modern species Lacinius angulifer (Simon, 1878) (see Roewer, 1912: p. 77; Roewer, 1923: Fig. 915), L. dentiger (Fig. 3a), L. ephippiatus (Koch, 1835) (see Šilhavý, 1956: Table VII, Fig. 28; Martens, 1978: Fig. 619), L. insularis Roewer, 1923 (see Roewer, 1923: Fig. 918), and Lacinius texanus (Banks, 1893) (see Banks, 1901: Fig. 4; Roewer, 1912: p. 81; Roewer, 1923: p. 743). The fossils thus have more in common in terms of their external morphology with species like L. horridus (Panzer, 1794) (Fig. 3b) and L. erinaceus. The most specific characteristic of the new Baltic amber fossil is the presence of well-developed apophyses on both the patella and tibia. Apophyses of this form are not present in Lacinius erinaceus (see e.g. Dunlop and Mitov, 2009, sub L. erinaceus, Figs. 28-29; Kurt and Erman, 2012, Fig. 5c, L. erinaceus). We re-examined the original Bitterfeld Lacinius record (MB.A. 1661). The original description

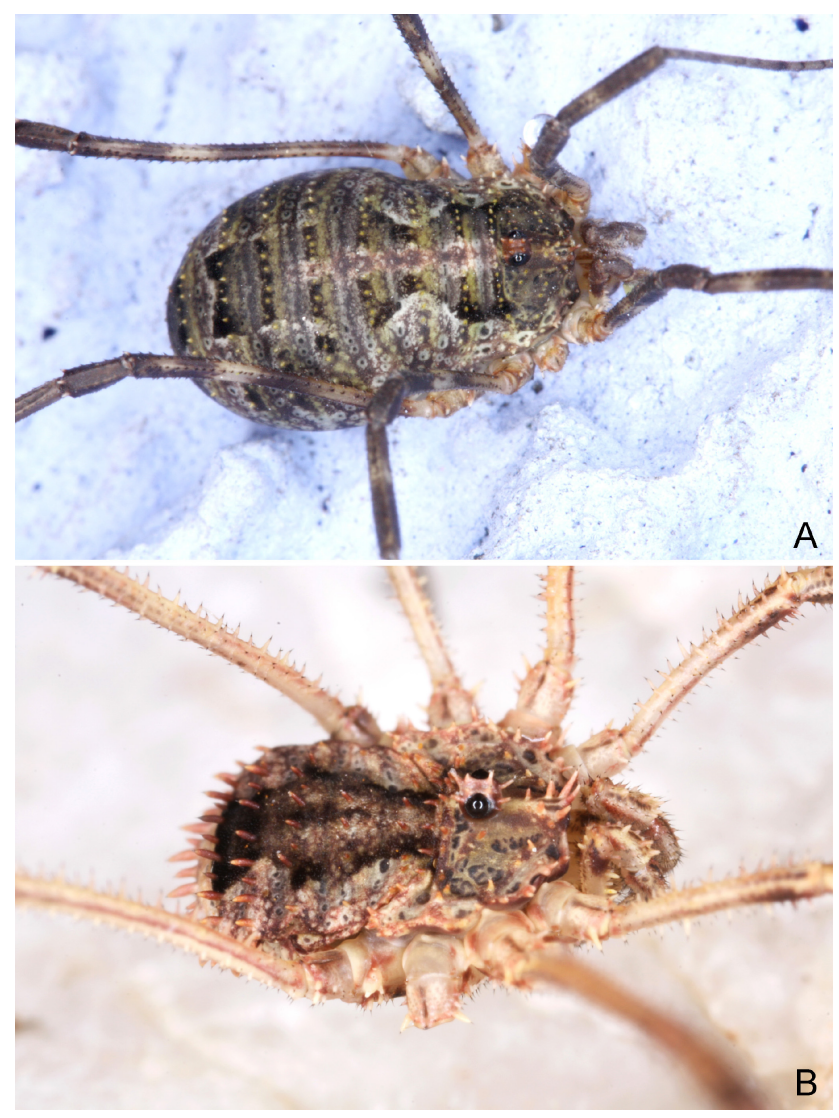

Figure 3. Comparative photographs of two of the more widespread recent European Lacinius species. (a) Female L. dentiger (Koch, 1848) from Graz, Austria. (b) The more heavily ornamented L. horridus (Panzer, 1795) male from Luberkogel, Austria. Images courtesy of Christian Komposch (Graz).

did not figure the pedipalps so clearly, but upon restudy, we could confirm that patellar and tibial apophyses are present here too. This suggests that the two fossil Lacinius records probably are conspecific, but differ from L. erinaceus and at least all the modern Palearctic species in this genus.

The closest potential match would be the North American species L. texanus Banks, 1893, for which Banks (1893, p. 403) stated that "The patella is prolonged, the inner side and prolongation being covered with short, stiff, black hairs. The tibia is enlarged at the end on the inner side and covered with similar hairs [...]". Unfortunately there is no illustration in the original description to show whether Bank's "prolongation" of the patella is a substantial apophysis as per the fossil specimens, but subsequent figures and/or redescriptions of L. texanus by Banks (1901, Fig. 4) and later Roewer (1912, p. 81; 1923, p. 743) do not indicate explicit pedipalpal apophyses. As noted above, the general habitus of L. texanus is also less spiny than our amber material, which argues against the fossils being closely related to the living American species.

On balance, we feel justified in proposing a new (fossil) Lacinius species diagnosed on the combination of body 
ornamentation and pedipalp morphology as above. As noted previously, the new specimen is quite small, and the individual may be immature. Where apophyses are present in phalangiid harvestmen, they can be more prominent in immature instars and become less well expressed in adults. We select the first specimen to be described (MB.A. 1661 from Bitterfeld amber) as the holotype of our new taxon. Since the second (Baltic) specimen is not from the same locality as the holotype, we chose not to treat it as a paratype. The Baltic example of Lacinius bizleyi sp. nov. places the genus back at least in the Eocene, and can also be added to the list of harvestmen found in both Baltic and Bitterfeld amber. The other harvestmen common to both ambers are the nemastomatid Histricostoma tuberculatum (Koch and Berendt, 1854), the caddid Caddo dentipalpus (Koch and Berendt, 1854), the phalangiid Dicranopalpus ramiger (Koch and Berendt, 1854) and the sclerosomatid Leiobunum longipes Menge, 1854. The Opiliones data thus remain preliminary, but our new fossil contributes to the debate (reviewed by, e.g., Standke, 2008, and Dunlop, 2010) about whether Baltic and Bitterfeld ambers are in fact contemporary deposits, sampling the same (implicitly Eocene) fauna. Alternatively, if Bitterfeld amber is a distinct and younger deposit - and not merely older Baltic amber reworked into younger sediments - it implies that there was something of a faunal continuum in the Paleogene of northern-central Europe. In other words, the same (morpho)species of harvestmen, and probably other arachnids too, can be found in the fossil record of this region of Europe across an Eocene-to-Oligocene time period which may correspond to about 25 million years.

Author contributions. P. G. Mitov and J. A. Dunlop compared the fossil to its living representatives; D. Penney provided the specimen and the data on amber in general. All authors contributed to the species description.

Acknowledgements. We thank Jonas Damzen (Vilnius) for donating this specimen to D. Penney for research purposes and Christian Neumann (MfN, Berlin) for curatorial assistance. We also thank Christian Komposch (Graz) for comparative images of modern Lacinius species and Nataly Snegovaya (Baku) for images of juvenile Asian Homolophus and Asian Lacinius species, and the reviewers for numerous helpful remarks. P. G. Mitov's visit to Berlin (DE-TAF-4010) was supported by the SYNTHESYS project (http://www.synthesys.info/), financed by the European Community Research Infrastructure action under the FP7 "Capacities" programme.

Edited by: F. Witzmann

Reviewed by: P. A. Selden and one anonymous referee

\section{References}

Banks, N.: A new American Lacinius, Psyche, 6, 402-403, 1893.

Banks, N.: Synopses of North-American invertebrates. XVI. The Phalangida, American Naturalist, 35, 669-679, 1901.

Chatzaki, M., Lymberakis, P., Mitov, P., and Mylonas, M.: Phenology of Opiliones on an altitudinal gradient on Lefka Ori Mountains, Crete, Greece, J. Arachnol., 37, 139-146, 2009.

Cokendolpher, J. C.: On the identity of the genus Homolophus: A senior synonym of Euphalangium (Opiliones: Phalangiidae), Acta Arachnologica, 35, 89-96, 1987.

Cokendolpher, J. C. and Lee, V. F.: Catalogue of the Cyphopalpatores and bibliography of the harvestmen (Arachnida, Opiliones) of Greenland, Canada, U.S.A., and Mexico, Privately Published, Vintage Press, Lubbock, Texas, 1993.

Çorak, İ., Bayram, A., Karol, S., Danışman, T., Sancak, Z., and Yiğit, N.: A new record for the harvestmen fauna of Turkey: Lacinius ephippiatus (C.L. Koch, 1835) (Opiliones, Phalangiidae), Turkish Journal of Arachnology, 1, 114-117, 2008.

Çorak Öcal, İ., Yiğit Kayhan, N., Bayram, A., Danişman, T., and Sancak, Z.: Harvestmen records from the Köprülü Canyon National Park, Antalya (Arachnida: Opiliones), Munis Entomology and Zooology, 9, 71-79, 2014.

Crawford, R. L.: Catalogue of the genera and type species of the harvestman superfamily Phalangioidea (Arachnida), Burke Museum Contributions in Anthropology and Natural History, 8, 160, 1992.

Crosby, C. R. and Bishop, S. C.: Notes on the Opiliones of the southeastern United States with descriptions of new species, Journal Elisha Mitchell Scientific Society, 40, 8-26, 1924.

Delfosse, E.: Addenda et corrigenda du catalogue préliminaire des Opilions de France métropolitaine de 2004 (Arachnida, Opiliones), Le bulletin d'Arthropoda, 47, 5-26, 2014.

Dunlop, J. A.: Bitterfeld amber, in: Biodiversity of fossils in amber from the major world deposits, edited by: Penney, D., Siri Scientific Press, Manchester, 57-68, 2010.

Dunlop, J. A. and Mitov, P. G.: Fossil harvestmen (Arachnida, Opiliones) from Bitterfeld amber, Zookeys, 16, 347-375, 2009.

Hallan, J.: The Biology Catalog - Opiliones. "Phalangiidae Species Listing", Texas A\&M University, available at: https://insects.tamu.edu/research/collection/hallan/Acari/ Family/Phalangiidae.txt (last access: 8 June 2014), 2005.

Kraus, O.: Weberknechte aus Spanien (Arachn., Opiliones), Mitteilungen aus dem Zoologischen Museum in Berlin, 35, 293 304, 1959.

Kraus, O.: Die Weberknechte der Iberischen Halbinsel (Arach., Opiliones), Senckenbergiana biologica, 42, 331-363, 1961.

Kurt, K. and Erman, Ö. K.: The first record of the species Lacinius erinaceus Staręga, 1966 (Opiliones, Phalangiidae) in Turkey with some SEM studies on its morphology, Archives of Biological Science, Belgrade, 64, 659-665, 2012.

Li, S.-Q. and Song, D.-X.: A revision of Chinese harvestmen, with a note on their geographical distribution, Scientific Treatise on Systematic and Evolutionary Zoology, 2, 237-245, 1993.

Marcellino, I.: Opilioni Italiani del genere Lacinius Thorell, 1876 (Arachnida, Opiliones, Phalangiidae), Fragmenta Entomologica, 11, 149-168, 1975.

Martens, J.: Zoologische Aufsammlungen auf Kreta III. Opiliones, Annalen des Naturhistorischen Museums in Wien, 69, 347-362, 1966. 
Martens, J.: Spinnentiere, Arachnida, Weberknechte, Opiliones, Die Tierwelt Deutschlands,64, Teil. Gustav Fischer Verlag, Jena, 1978.

Novak, T.: An overview of harvestmen (Arachnida: Opiliones) in Bosnia and Herzegovina, Natura Croatica, Zagreb, 14, 301-350, 2005.

Prieto, C. E.: Primera actualización de la Check-list de los Opiliones de la Peninsula Ibérica e Islas Baleares, Revista Ibérica de Aracnología, 8, 125-141, 2003.

Prieto, C. E.: Updating the checklist of the Iberian opiliofauna: corrections, suppressions and additions, Revista Ibérica de Aracnología, 16 [for 2007], 49-65, 2008.

Roewer, C. F.: Revision der Opiliones Palpatores (= Opiliones Plagiostethi). II. Teil: Familie der Phalangiidae. (Subfamilien: Sclerosomini, Oligolophini, Phalangiini), Abhandlungen aus dem Gebiete der Naturwissenschaften, herausgegeben vom Naturwissenschaftlichen Verein in Hamburg, 20, 1-295, 1912.

Roewer, C. F.: Die Weberknechte der Erde. Systematische Bearbeitung der bisher bekannten Opiliones, Gustav Fischer, Jena, 1923.

Roewer, C.-F.: Über Phalangiinae (Phalangiidae, Opiliones Palpatores). (Weitere Weberknechte XIX), Senckenbergiana Biologica, Frankfurt, 37, 247-318, 1956.

Roewer, C.-F.: Über Oligolophinae, Caddoinae, Sclerosomatinae, Leiobuninae, Neopilioninae und Leptobuninae (Phalangiidae, Opiliones Palpatores), (Weitere Weberknechte XX), Senckenbergiana Biologica, Frankfurt 38, 323-358, 1957.

Roewer, C.-F.: Die Araneae, Solifuga und Opiliones der Sammlungen des Herrn Dr. K. Lindberg aus Griechenland, Creta, Anatolien, Iran und Indien, Göteborgs Kungliga Vetenskapsoch Vitterhets-Samhälles handlingar, Göteborg, Ser. B, Matematiska och naturvetenskapliga skrifter, 8, 1-47, 1959.

Rozwałka, R., Sienkiewicz, P., and Staręga, W.: Distribution of Lacinius dentiger (C. L. Koch, 1847) (Arachnida: Opiliones) in Poland, Annales Universitatis Marie Curie-Skłodowska Lublin Polonia Sectio C, 65, 67-72, 2010.
Sánchez-Cuenca, D. and Prieto, C. E.: Odiellus ramblae sp. n., a new species from Catalonia (España), with a key to the Iberian species of the genus Odiellus Roewer, 1923 (Opiliones, Phalangiidae), Revista Ibérica de Aracnología, 24, 19-27, 2014.

Schönhofer, A.: A taxonomic catalogue of the Dyspnoi Hansen and Sørensen, 1904 (Arachnida: Opiliones), Zootaxa, 3679, 1-68, 2013.

Šilhavý, V.: Sekáči-Opilionidea, Fauna ČSR 7, ČSAV, Praha, 1956.

Šilhavý, V.: Die Weberknechte der Unterordnung Eupnoi aus Bulgarien; zugleich eine Revision Europäischer Gattungen der Unterfamilien Oligolophinae und Phalangiinae (Arachnoidea, Opilionidea), Ergebnisse der zoologischen Expedition des Tschechoslowakischen Akademie des Wissenschaften nach Bulgarien im Jahre 1957 (Teil V). Ceskoslovenská Spolecnost Entomologická [= Acta Entomologica Bohemoslovaca], Praha 62: 369406, 1965.

Simon, E.: Descriptions d'Opiliones (faucheurs) nouveaux de la faune circa-Méditerranéenne, Annales de la Société de Belgique, Bruxelles 21 (Comptes-Rendus): ccxv-ccxxiv, 1878.

Snegovaya, N. Y.: A new harvestman species (Arachnida: Opiliones: Phalangiidae: Homolophus) from Nakhichevan Autonomous Republic (Azerbaijan), Fragmenta Faunistica, 55, 5$10,2012$.

Standke, G.: Bitterfeld Bernstein gleich Baltischer Bernstein? - eine geologische Raum- Zeit- Betrachtung und genetische Schlussfolgerungen, Exkursionsführer und Veröffentlichungen der Deutschen Gesellschaft für Geowissenschaften, 236, 11-33, 2008.

Staręga, W.: Beitrag zur Kenntnis der Weberknecht-Fauna (Opiliones) der Kaukasuslander, Annales Zoologici, 23, 387-411, 1966.

Starega, W.: Die Weberknechte (Opiliones, excl. Sironidae) Bulgariens, Annales Zoologici, 33, 287-433, 1976.

Wang, F.-C.: A list of Chinese spiders of the order Opiliones. Kunchong-xuebao: jikan = Acta entomologica Sinica/Zhongguo Kunchong Xuehui zhuban. Kunchong-xuebao Bianji Weiyuanhui bianji, Beijing: Kexue Chubanshe, 3, 503-512, 1953. 